\title{
Economics of Fermentation of Poultry Farm Waste
}

\author{
I. A. Baba ${ }^{*}$, M. T. Banday, H. M. Khan, A. A. Khan, A. Akhand and M. Untoo
}

Division of Livestock Production and Management, Faculty of Veterinary Sciences and Animal Husbandry Shuhama, Sheri-e-Kashmir University of Agricultural Sciences and Technology of Kashmir, India

*Corresponding author

\begin{abstract}
A B S T R A C T
Present study was conducted during the year 2016 (January-March for winter trail and May-July for summer trail) to assess the economics of fermentation of poultry farm waste

\begin{tabular}{|c|}
\hline Keywords \\
\hline $\begin{array}{l}\text { Fermentation, } \\
\text { Economics, Poultry } \\
\text { birds, Litter }\end{array}$ \\
\hline Article Info \\
\hline $\begin{array}{l}\text { Accepted: } \\
20 \text { May } 2018 \\
\text { Available Online: } \\
\text { 10 June } 2018\end{array}$ \\
\hline
\end{tabular}
under the agro-climatic conditions of Kashmir Valley in the Division of Livestock Production and Management, Faculty of Veterinary Sciences and Animal Husbandry (SKUAST- Kashmir). Poultry farm waste in the form of poultry carcass and poultry litter was selected for this purpose. nine treatments formulated for fermentation were: $T_{1}$ : Poultry carcass + Poultry litter, $\mathrm{T}_{2}:$ Poultry carcass + Poultry litter + Lactobacillus @ $1.0 \%$, $\mathrm{T}_{3}$ :Poultry carcass + Poultry litter + Lactobacillus @ $0.5 \%, \mathrm{~T}_{4}$ : Poultry carcass + Poultry litter + Yeast @1.0\%, $\mathrm{T}_{5}$ : Poultry carcass +Poultry litter + Yeast @ $0.5 \%, \mathrm{~T}_{6}$ : Poultry carcass + Poultry litter + Lactobacillus@1\% + Yeast @ 0.5\%, $\mathrm{T}_{7}$ : Poultry carcass + Poultry litter + Lactobacillus @ 1\% + Yeast @ 1\%, $\mathrm{T}_{8}$ : Poultry carcass + Poultry litter + Lactobacillus@0.5\% + Yeast @ 0.5\% and $\mathrm{T}_{9}$ : Poultry carcass + Poultry litter + Lactobacillus@0.5\% + Yeast @1\%. Each treatment was having three replicates. The total profit for fermentation (winter + summer) was highest (Rs. 127.51) in $\mathrm{T}_{6}$ and lowest (Rs. 121.85) in $T_{3}$. Net profit per bin was highest (Rs. 5.67) in $T_{8}$ and lowest (Rs. 86.04) in $T_{2}$. Similarly profit/kg of end product was highest (Rs. 3.12) in $T_{1}$ and lowest (Rs. 2.99) in $T_{6}$.
\end{abstract}

\section{Introduction}

The poultry industry in India now is the fastest growing segment of the livestock sector with $12.39 \%$ present annual growth rate (Anon. 2015). With high levels of concentrated production, it involves generation of large volumes of waste. One of the major problems currently faced by the poultry industry is the accumulation of a large amount of waste especially manure and litter generated by intensive production which poses different environmental, social and economic problems, requiring prompt and regular removal and disposal of such waste for proper bio-security (Bolan, 2010). Fermentation of poultry carcasses is a bio-secure method of disposal and utilization of mortalities and farm waste. It is an anaerobic process in which lactic acid bacteria transform sugar into lactic acid which is a naturally low $\mathrm{pH}$ effective preservative agent (Cai and Pancorbo, 1994). The lactic acid fermentation helps in decontamination of carcass material and further utilization of the end product as fermented feed for other animals (Crews et al., 1995). Thus, the use of 
fermentation processes for recycling and transformation of wastes may be a good way to ensure the safety of the obtained products and offers a way for further utilization of the disposed end product in future.

\section{Materials and Methods}

Fermentation of the poultry farm waste (dead birds and poultry litter) was carried out at Division of LPM under a roofed shed. The fermentation process was carried out in air tight plastic containers. Dead birds and poultry litter in 1:1 ratio was fermented in different combinations. Poultry waste was humidified with tap water in the proportion of $1: 1$ and the $\mathrm{pH}$ was adjusted to 6.5 with $50 \% \mathrm{H}_{2} \mathrm{SO}_{4}$ solution (El-Jalil et al., 2008). A total of nine treatments (with three replicates in each treatment) with different individual as well as combination levels of culture of Lactobacillus acidophilus and Yeast (Saccharomyces cerevisiae) was used as shown in Table: 1. Dead birds and poultry litter was collected from local poultry farms. The dead birds were stored at $-5^{\circ} \mathrm{C}$ till sufficient materials were made available to fill all the containers in a single day. On the receipt of sufficient quantity of carcasses and poultry litter, the filling of fermentation containers was carried out uniformly.

\section{Assumptions}

The cost of production of dead bird and litter fermented end product was worked out with following assumptions:

The cost of plastic air tight containers was Rs. 30.00 per bin and was used for both seasons

The plastic bins were sufficient to last at least for five years (ten experiments).

The cost of $1 \%$ Lactobacillus acidophilus/ $1 \%$ Yeast was estimated Rs. 2.
The cost of molasses was Rs. $2 / \mathrm{kg}$.

The labour cost for chopping of carcass, loading and mixing of carcass and transportation cost was worked out as Rs. 5.0 per treatment.

Dead birds were received free of cost.

Poultry litter was also received free of cost

Value of end product/Kg was Rs. 4.31 (Anon. 2016).

In the present study the plastic containers were used for both the seasons of fermentation. But, in field conditions, the containers will be useful for 4-5 years of fermentation.

The cost involved in fermentation of poultry farm waste (dead bird and litter) was worked out with variable cost alone excluding cost of litter and dead birds because they were collected at free of cost.

The economics was worked out as follows:

Fixed cost

Cost of plastic containers

Variable cost

Cost of loading, molasses and transportation of poultry carcass and poultry litter and labour etc.

Total cost involved: I + II

Gross profit

The gross revenue was worked out based on fertilizer value of compost which was kept as Rs. $4.31 / \mathrm{kg}$ of ferment

Net revenue: VI - III 


\section{Statistical analysis}

The data collected was statistically analyzed as per the methods suggested by Snedecor and Cochran (1994).

\section{Results and Discussion}

The fixed cost involved was Rs. 9.0 during winter summer seasons in all treatment groups. Similarly variable cost involved ranged between Rs. 7.0 in $\mathrm{T}_{1}$ (control group) and Rs. 11.0 in treatment group $\mathrm{T}_{7}$ during both the seasons (Table. 2). The total cost involved in fermentation process varied between Rs. 16 in $\mathrm{T}_{1}$ (control group) and Rs. 20.0 in $\mathrm{T}_{7}$ during both the seasons. The total profit of fermentation (winter + summer) was highest with Rs. 91.51 in $\mathrm{T}_{8}$ (in which Lactobacillus@ $0.5 \%$ and Yeast@0.5 was added) and lowest with Rs. 86.04 in $\mathrm{T}_{2}$ (in which Lactobacillus@ $1 \%$ was added). The profit per $\mathrm{kg}$ of end product was Rs. 3.19 highest and Rs. 2.94 as lowest in treatment group $\mathrm{T}_{1}$ (control group) and in $\mathrm{T}_{7}$ (containing Lactobacillus@ 1\% and Yeast@ 1\%) respectively. The fixed cost which involved cost of plastic containers and same in all treatment groups with Rs. 9.0 during winter and summer seasons keeping in view the life of the containers (Sakaridis et al.,
2014). Similarly variable cost involved ranged between Rs. 7.0 in $T_{1}$ (control group) and Rs. 11.0 in treatment group $\mathrm{T}_{7}$ in both the seasons because of the different levels of Lactobacillus acidophilus were used (Fransen, 1995). The total cost involved in fermentation process varied between Rs. 16 in $T_{1}$ (control group) and Rs. 20.0 in $\mathrm{T}_{7}$ during both the seasons. The total profit of fermentation (winter + summer) was highest of Rs. 91.51 in $\mathrm{T}_{8}$ (in which Lactobacillus@ 0.5\% and Yeast@ 0.5 was added) and lowest of Rs. 86.04 in $\mathrm{T}_{2}$ (in which Lactobacillus@1\% was added). The profit per $\mathrm{kg}$ of end product was Rs. 3.19 highest and Rs. 2.94 as lowest in treatment group $\mathrm{T}_{1}$ and in $\mathrm{T}_{7}$ (containing Lactobacillus@ 1\% and Yeast@1\%) respectively, because Lactobacillus acidophilus and Yeast was not incorporated $\mathrm{T}_{1}$ group. It was revealed that although the net profit (returns) were low, but with further continuity of the fermentation process round the year higher returns would be attained (Blake, 2004). Higher net higher net returns of 1200-2500 \$ per year were reported earlier by Cai and Pancorbo (1994) in fermentation of poultry carcass and litter. Similarly due to higher transportation and other charges, Murphy (1988) observed lower returns in the fermented end product of poultry carcass and litter.

Table.1 Treatment Combinations of Fermentation Experiment

\begin{tabular}{|c|c|}
\hline Treatments & Description \\
\hline Treatment 1 & Dead birds + Poultry litter \\
\hline Treatment 2 & Dead birds + Poultry litter + lactobacillus@ $1.0 \%$ \\
\hline Treatment 3 & Dead birds + Poultry litter + lactobacillus @ $0.5 \%$ \\
\hline Treatment 4 & Dead birds + Poultry litter + Yeast @ $1.0 \%$ \\
\hline Treatment 5 & Dead birds + Poultry litter + Yeast @ $0.5 \%$ \\
\hline Treatment 6 & Dead birds + Poultry litter + Lactobacillus@ 1\% + Yeast@ 0.5\% \\
\hline Treatment 7 & Dead birds + Poultry litter + Lactobacillus@1\%+Yeast@1\% \\
\hline Treatment 8 & Dead birds + Poultry litter + Lactobacillus@0.5\%+Yeast @0.5\% \\
\hline Treatment 9 & Dead birds + Poultry litter + Lactobacillus@ 0.5\%+ Yeast @1\% \\
\hline
\end{tabular}


Int.J.Curr.Microbiol.App.Sci (2018) 7(6): 2108-2112

Table.2 Economics of Fermentation

\begin{tabular}{|c|c|c|c|c|c|c|c|c|c|c|c|c|c|c|c|}
\hline \multirow[t]{2}{*}{ Treatment } & \multicolumn{2}{|c|}{ Fixed cost (Rs.) } & \multicolumn{2}{|c|}{$\begin{array}{l}\text { Variable cost } \\
\text { (Rs.) }\end{array}$} & \multicolumn{2}{|c|}{ Total cost (Rs.) } & \multicolumn{2}{|c|}{$\begin{array}{l}\text { End product } \\
\text { obtained (Kg) }\end{array}$} & \multicolumn{2}{|c|}{$\begin{array}{l}\text { Cost involved } \\
\text { /kg of end } \\
\text { product (Rs) }\end{array}$} & \multicolumn{2}{|c|}{ Profit (Rs.)* } & \multirow{2}{*}{$\begin{array}{c}\text { Total } \\
\text { Profit } \\
\text { (Winter+ } \\
\text { Summer) }\end{array}$} & \multirow{2}{*}{$\begin{array}{c}\begin{array}{c}\text { Net profit } \\
\text { (Rs) }\end{array} \\
\text { (Winter } \\
\text { +Summer) }\end{array}$} & \multirow{2}{*}{$\begin{array}{l}\text { Profit/Kg } \\
\text { end } \\
\text { product } \\
\text { (Rs.) }\end{array}$} \\
\hline & Winter & Summer & Winter & Summer & Winter & Summer & Winter & Summer & Winter & Summer & Winter & Summer & & & \\
\hline $\mathbf{T}_{1}$ & 9 & 9 & 7 & 7 & 16 & 16 & 14.15 & 14.38 & 1.13 & 1.11 & 61 & 61.98 & 122.98 & 90.98 & 3.19 \\
\hline $\begin{array}{c}\mathrm{T}_{2} \\
(\mathrm{LB}=\mathbf{1} \%)\end{array}$ & 9 & 9 & 9 & 9 & 18 & 18 & 14.3 & 14.02 & 1.26 & 1.28 & 61.62 & 60.42 & 122.04 & 86.04 & 3.04 \\
\hline $\begin{array}{c}\mathrm{T}_{3} \\
(\mathrm{LB}=0.5 \%)\end{array}$ & 9 & 9 & 8 & 8 & 17 & 17 & 13.92 & 14.35 & 1.22 & 1.18 & 60 & 61.85 & 121.85 & 87.85 & 3.11 \\
\hline $\begin{array}{c}\mathrm{T}_{4} \\
(\text { Yeast }=1 \%)\end{array}$ & 9 & 9 & 9 & 9 & 18 & 18 & 14.2 & 14.15 & 1.27 & 1.27 & 61.21 & 60.98 & 122.19 & 86.19 & 3.04 \\
\hline $\begin{array}{c}\mathrm{T}_{5} \\
(\text { Yeast }=0.5 \%)\end{array}$ & 9 & 9 & 8 & 8 & 17 & 17 & 13.93 & 14.5 & 1.22 & 1.17 & 60.03 & 62.5 & 122.53 & 88.53 & 3.12 \\
\hline $\begin{array}{c}\mathrm{T}_{6} \\
(\mathrm{LB}=1 \%+\text { Yeast }=0.5 \%)\end{array}$ & 9 & 9 & 10 & 10 & 19 & 19 & 14.18 & 14.63 & 1.34 & 1.3 & 61.1 & 63.06 & 124.16 & 86.16 & 2.99 \\
\hline $\mathbf{T}_{7}$ & 9 & 9 & 11 & 11 & 20 & 20 & 14.39 & 14.86 & 1.39 & 1.35 & 62.03 & 64.06 & 126.09 & 86.09 & 2.94 \\
\hline$(\mathrm{LB}=1 \%+$ Yeast $=1 \%)$ & & & & & & & & & & & & & & & \\
\hline $\begin{array}{c}\mathrm{T}_{8} \\
(\mathrm{LB}=\mathbf{0 . 5 +}+\text { Yeast }=0.5 \%)\end{array}$ & 9 & 9 & 9 & 9 & 18 & 18 & 14.5 & 15.08 & 1.24 & 1.19 & 62.5 & 65.01 & 127.51 & 91.51 & 3.10 \\
\hline $\begin{array}{c}\mathrm{T}_{9} \\
(\mathrm{LB}=0.5+\text { Yeast }=1 \%)\end{array}$ & 9 & 9 & 10 & 10 & 19 & 19 & 14.62 & 14.9 & 1.3 & 1.27 & 63 & 64.24 & 127.24 & 89.24 & 3.03 \\
\hline
\end{tabular}

Sale rate of end product was Rs. $4.31 / \mathrm{kg}$ 
It was concluded that lactic acid and Yeast fermentation of dead birds and poultry litter yielded appreciable economic benefits in terms of end product utilization and secure disposal of waste.

\section{References}

Anonymous, 2015. Annual Report of Department of Animal Husbandry, Dairying and Fisheries, Ministry of Agriculture, Govt. of India, 34.

Anonymous. 2016. Annual Report of Ministry of Fertilizers and Chemicals, Govt of India, 2016-17, 39.

Blake, JP, 2004. Methods and technologies for handling mortality losses. World's Poultry Science Journal, 60, 489-499.

Bolan, NS, Szogi, AA, Chuasavathi, TB, Seshadri, MJ, Rothrock JR, Panneerselvam, P. 2010. Uses and Management of Poultry Litter. World's Poultry Science Journal, 66, 673-698.

Cai, T, Pancorbo, OC, 1994. Chemical and Microbiological Characteristics of Poultry Processing Byproducts, Waste and Poultry Carcasses during Lactic Acid Fermentation, Journal of Applied Poultry Science Research, 3, 49-60.

Crews, JR, Donald JO, Blake, JP, 1995. An Economic Evaluation of Dead-bird
Disposal Systems. ANR-914.Alabama Cooperative Extension System. Blake and P. H. Patterson (editors). Proceedings of National Poultry Waste Management Symposium. Oct 30-Nov 02, Athens, Georgia, 304-309.

El-Jalil, MH, Zinedine, A, Faid, M, 2008. Some Microbiological and Chemical Properties of Poultry Wastes Manure after Lactic Acid Fermentation. International Journal of Agricultural Biology, 10, 405-411.

Fransen, HG, Urlings, BAP, Bukar, PHB, Gills, BGM. 1995. Utilization of Fermented Flocculated Poultry Sludge as a Feed Constituent for Pigs. Poultry Science, 74, 1948-1960.

Murphy, DW. 1988. Composting as a dead bird disposal method. Poultry Science, 67, 124.

Sakaridis, I, Soultos, N, Batzios, C, Ambrosiadis, I, Koidis, P. 2014. Lactic Acid Bacteria Isolated from Chicken Carcasses with Inhibitory Activity against Salmonella spp. and Listeria monocytogenes. Czech Journal Food Science, 32, 61-68.

Snedecor, GW, Cochran, WG. 1994. Statistical Methods 8th Edition, Iowa State Press, Ames, Iowa, USA, 254268.

\section{How to cite this article:}

Baba I. A., M. T. Banday, H. M. Khan, A. A. Khan, A. Akhand and Untoo M. 2018. Economics of Fermentation of Poultry Farm Waste. Int.J.Curr.Microbiol.App.Sci. 7(06): 21082112. doi: https://doi.org/10.20546/ijcmas.2018.706.250 